\title{
En kule
}

\section{뭄}

\section{livets flipperspill}

Å være lege i førstelinjen er et risikabelt prosjekt. Petter Brelin er nyvalgt leder for allmennlegenes faglige forening, den største i Legeforeningen. De 6000 medlemmene han har påtatt seg ansvar for, fatter sine mer eller mindre kunnskapsbaserte beslutninger i et kaos av usikre data, medisinsk ubeskrevne fenomener og lav prevalens for faktisk sykdom. Selv tar han ting som de kommer.

- Jeg er en ufattelig uspennende fyr, sier Petter Brelin entusiastisk. - Hvis noen skulle finne på å skrive en biografi om meg, ville det ikke bli mange sidene. Jeg er en middelmådig, middelaldrende fyr i V-genser.

- Petter ferdes i verden som om han nylig har landet fra Mars, sier en kollega som har samarbeidet nært med ham. - Han tar ingenting for gitt.

Siden september har Petter Brelin hatt vikar i praksisen i Halden og selv gått i rute mellom Legenes hus og nyinnkjøpt leilighet nederst på Grønland, der han er del av en etnisk og sosioøkonomisk minoritet. Han blir ubekvem ved tanken på at noen skulle tro at valget av bosted er et slags kokett solidaritetsprosjekt.

- Jeg kjøpte det jeg hadde råd til. Når det er sagt, er det spennende å bo midt $\mathrm{i}$ den nye urbaniteten, å observere de sterke motsetningene på kloss hold. Her om kvelden ble jeg stoppet på vei hjem fra et møte, av to menn i Vaterlandsparken. Jeg hadde på meg en blazer som jeg har arvet, en sånn gammeldags med metallknapper. Den bruker jeg når jeg må være litt formell. Den ene mannen spurte om jeg kom fra PST samtidig som den andre tilbød meg hasj. Det er mye jeg ikke skjønner bæret av.

Petter Brelin er kjent for pasienter og kolleger som effektiv, dedikert og forutsigbar. Man kan stole på ham. «Han leverer», heter det vel i dagens markedstilpassede retorikk, men gjør lite nummer av sine mange roller og oppdrag. Det var nok noen på årsmøtet til Norsk forening for allmennmedisin $\mathrm{i}$ vår som ble overrasket da hans rikholdige portefølje ble synliggjort i forbindelse med valget på ny leder. Likevel er det utenfor skjemaet, i digresjonene og tankesprangene, at Petter Brelin blir virkelig interessant. Skjønt «interessant» - selv vil han nok foretrekke den mer presise karakteristikken «dritkul». Vi snakker alle fra et sted. Petter har far fra Vålerenga og mor fra indre Oslo og er selv oppvokst på Manglerud, en av hovedstadens første drabantbyer.

\section{Verden av i går}

- Manglerud da jeg vokste opp var preget av masse unger på omtrent samme alder. Alle bodde i omtrent like leiligheter bygd i 1960- og 70-årene. Det var trygt og greit, men man måtte jo holde seg litt $i$ orden. Ikke forvente at det skulle gå bra uten videre. Avstanden til bunnen var ikke så

\section{«Petter ferdes i verden som om han nylig har landet fra Mars»}

stor. Som barn var jeg en innegris, gadd ikke å leke med de andre. Jeg likte meg best sammen med mutter'n. Men på den tiden hadde mødrene fătt det for seg at det var sunt å være ute, så vi ble pælma ut uansett vær og føreforhold og fikk ikke slippe inn igjen før det hadde gått noen timer. Jeg husker at jeg sto påkledd ute i kulden og ringte på med jevne mellomrom. Det var sikkert bra. I dag ville jeg vel vært en asosial spillenerd.

- Hvorfor lege?

- Fatter'n overtok et bakeri, jobbet en stund på fabrikk og bygde siden opp et nytt bakeri. Han var en urkraft. Det var ingen med høyere utdanning i den delen av familien. Mutter'n hadde gått gymnaset og ville ha studert jus, men så ble jeg født, og hun ble hjemmeværende husmor, slik det jo var på den tiden. Det er fra henne jeg har de akademiske ambisjonene.

I diktet Gledespunkter gir poeten Kolbjørn Falkeid til kjenne sin beundring for oppkomlingen som «brøyter seg vei gjennom den tørre fernissen av god smak, tradisjon og tredjegenerasjonsgress». Den foraktede oppkomlingen sammenliknes med et neshorn som finner kilden og tømmer den. Petter Brelin kom ikke inn på medisinstudiet i Bergen på ordinært vis. Heller ikke ved å opparbeide seg reglementerte ekstrapoeng. Han maste seg bokstavelig talt inn til kilden, til kunnskapen. På hans kull ble det tatt opp én student ekstra. Det vitner om ett eller annet.

- Jeg var ikke så opptatt av å bli lege, men jeg hadde et brennende ønske om å være medisinstudent. Jeg lengtet inn i auditoriet, til biologi og fysiologi.

Det finnes en viktig milepæl i denne historien. Petter Brelins første møte med medisinstudenter var som ledsager for mor som skulle snakke til studentene om livet som kreftpasient. Petter var tenåring da moren ble syk, knapt 20 år gammel da hun døde. Moren var nesten ikke innlagt på sykehus og fikk dø hjemme slik hun ønsket. Det var uvanlig den gangen. Faren pleide henne selv, så å si uten andre hjelpere, til det siste.

- Det hender jeg spør meg selv om det var riktig. Vi stiller det spørsmålet for sjelden når suksesshistoriene om den gode hjemmedød løftes frem.

Omtrent samtidig med morens død ble Petter Brelin innkalt til militærtjeneste.

- Det var den ultimate meningsløshet. Å stå der, mørk til sinns, og passe på Skaugum mens man fikk kjeft av en undersetsig fenrik fra Eidsvoll. Det vekket i alle 


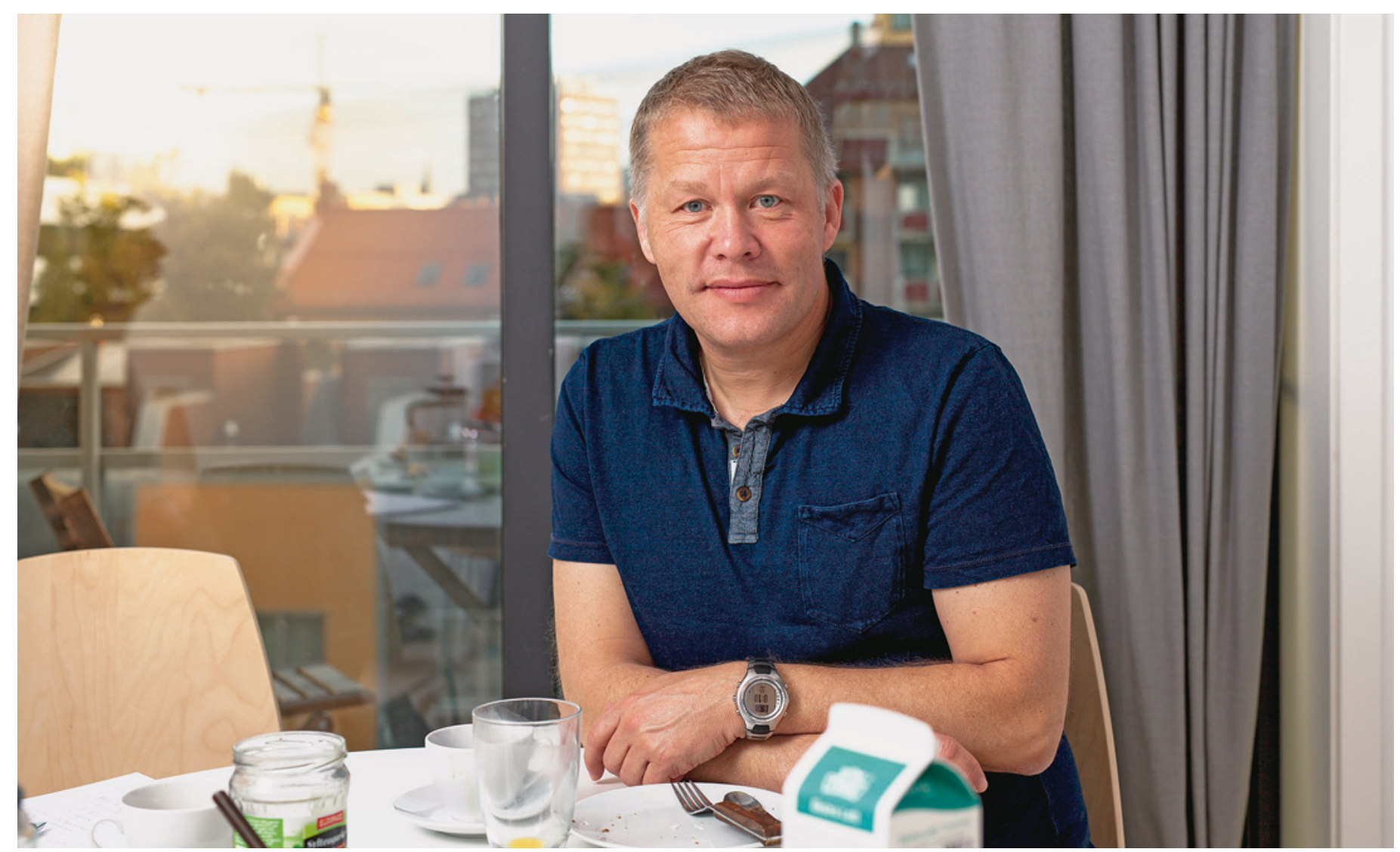

Foto: Niklas Lello

\section{Petter Brelin}

Født 1962 i Oslo

- Cand.med., Universitetet i Bergen 1990

- Spesialist i allmennmedisin

- Kommunelege og fastlege, Aremark, 1992-2002

- Fastlege, Halden, 2002-dd

- Praksiskoordinator, Sykehuset Østfold

- Mangeårig styremedlem, nå nestleder, Sykehuset Østfold

- Styreleder, Senter for kvalitet i legekontor (SKIL)

- Leder av Norsk forening for allmennmedisin (NFA) fall et sterkt ønske i meg om å bidra på meningsfullt vis i verden.

\section{Kunnskapens tre og andre buskvekster}

- Når amerikanerne og iranerne krangler, leser jeg Tehran Times. Man må jo undersøke hvordan de snakker om dette selv, de som er involvert på alle sider. I komplekse politiske situasjoner er det ikke tilstrekkelig å få det som skjer presentert gjennom norske eller vestlige journalisters filter.

Dette er et symptomatisk utsagn fra Petter Brelin. Når han blir interessert i et fenomen det være seg operamusikk, finanskrise eller hvordan et robotfjøs fungerer - nærmer han seg det med vidåpne spørsmål og appetitt som en guttunge i vekstspurten. Han leser daglig de norske avisene på nett, engelske Guardian, The Economist og oftest flere. Under Kashmir-krisen i 1998 begynte han å følge pakistanske The Dawn og indiske Times of India regelmessig.

Petter Brelin gikk også sine egne veier da store deler av det allmennmedisinske miljøet gikk kritisk ut mot evidensbasert medisin (EBM) tidlig i 1990-årene.

- Cochrane-bølgen traff meg i 1992. Jeg var begeistret. Jeg er fortsatt begeistret $i$ den grad kunnskapsbaserte oppsummeringer trumfer påstander fra lokale selvoppnevnte småkonger i faget. Evidensbasert medisin satte for eksempel allmennlegene i stand til å si til overleger i kardiologi at «det du sier der, høres rart ut». Å systematisere kunnskap og gjøre den allment tilgjengelig er demokratiserende.

- Men ser vi ikke nå tendenser til en vulgarisering av såkalt evidens? At begrepet «evidens» blir brukt til å legge faget i rør, så å si?

- Når nærheten mellom kunnskapsbyråkratiet og helsebyråkratiet blir påtrengende, er det grunn til å bekymre seg. Jeg er skeptisk til et kunnskapsbyråkrati som har vokst formidabelt og dertil holder seg med en egen retorikk som grenser til propaganda. Det har utviklet seg en revisorholdning som handler mer om å produsere evidens som kan uttrykkes i p-verdier enn kunnskap som er klinisk nyttig. Ideen om at gruppegenerert evidens uten videre kan omsettes til klinisk praksis på individnivå er dessuten overdrevet og feilaktig. Jeg savner mer klinisk forskning på pasientforløp. Hva virker og hvorfor? Mye helsetjenesteforskning er meningsløs. Vi trenger eksempelvis ikke forske for å finne ut om fastlegeordningen er en god idé eller om en offentlig finansiert, solidarisk helsetjeneste er kostnadseffektiv. 


\section{Velferdsstat og legemakt}

Petter Brelin beskriver seg selv som «veldig sosialdemokrat».

- Velferdsstaten er en fabelaktig konstruksjon. Den er billig, ivaretakende og humanistisk. Dessuten fungerer den norske velferdsmodellen så bra. Men den er avhengig av en sterk legeforening.

- Hva?!

- Helsebyråkratiet har en tendens til å bli sitt eget mål. Vi trenger myndighetsuavhengige organer som leverer premisser ut fra faglige hensyn. Jeg mener Legeforeningen leverer ryddige og skikkelige innspill i prosesser der vi blir invitert.

- Hva med habiliteten når de faglige rådene kommer fra fagforeningen som først og fremst skal ivareta medlemmenes egeninteresser?

- Jeg ser dilemmaet i teorien, men opplever det lite i praksis. Likevel handler jo habilitet om hvordan andre tolker oss, vi må alltid være skjerpet i så måte. Det jeg ikke skjønner, er at ikke myndighetene i større grad går til de beste i faget - representert ved engasjerte medlemmer i de fagmedisinske foreningene - når de skal søke råd. Man må vel eksempelvis anta at det skjer noe med folk når de får budsjettansvar. Det er ikke sikkert de faglige rådene fra en avdelingsoverlege i et helseforetak er upåvirket av konsekvensene på kort sikt for legens egen avdeling. «Legemakt» er et negativt ladet ord. Jeg synes det bør ses på som en verdi at legene forvalter makt $i$ betydningen tillit, det er tross alt vi som vet mest om hva som er god behandling for pasientene. Dermed er det ikke sagt at faget alltid er enig med seg selv. Faglig uenighet er ikke noe vi skal være redde for, tvert om. Se på den brennaktuelle debatten om overdiagnostikk og overbehandling! Den kommer ikke som resultat av et myndighetspålegg, men fra faget selv, en selvkritisk og sunn refleks.

\section{Hva er virksomt?}

- Tror du breddetilnærmingen som allmennmedisinen representerer står seg i en tid der kunnskapen blir stadig mer spesialisert og fragmentert?

- Det aldrende Europa trenger allmennleger mer enn noen gang. Både ytre rammebetingelser og praktiske nødvendigheter tilsier at stadig mer behandling må skje utenfor sykehusene. I en tid der kunnskapen globaliseres og gjøres tilgjengelig for alle, oppstår det også et sterkt behov for noen som kan tolke kaos for folk flest. «Betyr dette at jeg har kreft?» spør pasientene. Da er det fint å ha en personlig lege man stoler på som kan svare «nei». Nesten alltid.
Petter Brelin snakker seg varm om kjerneverdiene i fastlegeordningen. Hvorfor er den så populær? Hvorfor bytter ikke folk lege oftere?

- De to viktigste forutsetningene er den personlige relasjonen mellom legen og pasienten og kontinuiteten i forholdet. De henger sammen, men er ikke det samme. Over tid blir legen en person for pasienten. Over tid blir pasienten en person for legen. Kontinuitet og forutsigbarhet $\mathrm{i}$ behandlingen kan antakelig i noen grad ivaretas selv

\section{«Allmennmedisin kan ikke læres i sykehus»}

om legen er fratatt det personlige ansvaret, men da beveger man seg i retning av et regulært kundeforhold. Det er et reelt trusselbilde vi må forholde oss til i nær fremtid, med allmennmedisinske privatfinansierte «trusts» eller integrering av primærhelsetjenesten i en helseforetaksmodell. For meg er det viktig å holde fast ved legens personlige ansvar for sine pasienter. Vi ser jo hvor viktig det er for pasientene å komme til sin lege, en de kjenner og som kjenner dem. Det blir bare viktigere etter hvert som vi får flere pasienter som vil trenge oppfølging i mange år for sykdommer de tidligere døde av, men nå lever med.

Han er «dritforbanna» over myndighetens forslag om å legge spesialiseringen av allmennleger til helseforetakene. Et av hans første utspill som ny leder i Norsk forening for allmennmedisin var følgende kraftsalve på forsiden av Dagens Medisin: «Å gi helseforetakene ansvaret for allmennlegenes utdanning er like relevant som å legge nevrokirurgi inn under kommunen.» Han mistenker at noen har villet konstruere en utdanningsmodell som ser ren og ryddig ut og «lett kan puttes inn i PowerPoint».

- Poenget er ikke at allmennmedisinen ønsker å være seg selv nok. Poenget er at allmennmedisin ikke kan læres i sykehus, vi trenger avstanden til sykehusmedisinen.

- Jeg er egentlig fornøyd med den nevrokirurgimetaforen, legger han til. - Man kan ikke alltid snakke i diplomatiske vendinger. Det er ikke der jeg har min styrke.

\section{Man vet hva man har}

Som ung hadde han en hang til undergangsvisjoner og apokalyptisk historiefortolkning. Petter Brelin tror ikke lenger at alt går til helvete.

- Jeg har ingen sans for nihilisme, sier han og refererer til den svenske legen, tallknuseren og vidunderpedagogen Hans Rosling hvis videoer går sin optimistiske seiersgang verden over.

«Shit happens». For åtte år siden satt Petter Brelin i Halden og rev emballasjen av sitt nyervervede pent brukte ultralydutstyr, kjøpt usett fra Los Angeles til den nette sum av 80000 kroner. Han hadde gått på kurs og gledet seg som en unge til å ta apparatet $\mathrm{i}$ bruk. Først testet han det på seg selv.

- Det eneste jeg visste hvordan skulle se ut, var en full blære. Den skal være helt svart. Det var ikke min.

Han regner seg som frisk av blærekreften nå, men kan kjenne på uroen i forkant av kontrollene. Samtalen med de tre barna rundt kjøkkenbordet da sykdommen var nyoppdaget beskriver han som et mareritt.

- Jeg var ikke redd, men fryktelig lei meg. Hvor lenge kom de til å ha faren sin?

Petter Brelins nå voksne barn er heldige. Det er få relativt nyskilte fedre i 50-årene som med samme uforbeholdne glede forteller at da den yngste datteren på 19 år hørte at pappa hadde kjøpt leilighet i Oslo, bestemte hun seg sporenstreks for at hun og kjæresten også kunne bo der. De fikk det store soverommet. Petter Brelin ligger på det som eiendomsmegleren sikkert har kalt «barnerommet», med plass til en enkeltseng og en hylle. Hjemmet har et umiskjennelig preg av ungdommelig kollektiv. Far betaler husleien.

- Det er så utrolig hyggelig å bo sammen med dem, sier han.

\section{Eders tale skal være ja, ja, nei, nei}

Intervjuet er en langstrakt, assosiasjonsrik, usensurert samtale over et knapt døgn. Fotograf er bestilt til frokost. Petter Brelin er litt ukomfortabel der han poserer dagen derpå mellom ost og bløtkokte egg. Over kjøkkenbordet henger en diger fotokopi av hodet til Michelangelos David. Han David altså - er tidløst vakker.

- Folk som sier at «jeg blir alltid så stygg på bilder», må innse at de er stygge, sier Petter Brelin.

Allmennlegene har fått en leder med en velutviklet radar for tilsløring og tull, og et tilhørende talent for direkte tale.

\section{Elisabeth Swensen}

elswense@online.no 